\title{
DISKURSUS KAJIAN GENDER
}

\section{DALAM KITAB SUCI AL-QUR'AN}

\section{Siti Masykuroh}

Universitas Islam Negeri Raden Intan Lampung

masykurohsiti@yahoo.co.id

\section{Abstract}

The focus of this research is the study of the themes of the themes presented by the Koran about the status and role of women and how they are interpreted when they are projected in a frame of justice and gender equality. This research is pure literature, data is extracted from books, Tafsir verses of the Qur'an and al-Hadis as the main and first source. The analysis used in this study is a gender perspective. To sharpen the analyst also used social theories, such as; class analysis, cultural analysis and discourse analysis. From the results of the study found that the themes displayed by the Koran, revolve around the themes of the creation of men and women, equality of men and women, leadership, inheritance and polygamy. Discussions on these themes can be understood that the ideals of the Qur'an are actually the upholding of buman life with virtuous morality and respect for universal buman values (universal bumanism). These universal bumanitarian principles are manifested in efforts to uphold justice, equality, togetherness, and respect for the rights of others that are universally applicable.

\section{Abstrak}

Fokus penelitian ini adalah kajian tema tema yang ditampilkan al-Qur'an tentang status dan peran perempuan serta bagaimana interpretasi tema-tema tersebut ketika diproyeksikan dalam bingkai keadilan dan kesetaraan gender. Penelitian ini bersifat kepustakaan murni, data digali dari buku-buku, Tafsir 
ayat al-Qur'an dan al-Hadiś sebagai sumber utama dan pertama. Analisis yang digunakan dalam penelitian ini adalah perspektif gender. Untuk. mempertajam analis juga digunakan teori social, seperti; analisis kelas, analisis kultural dan analisis diskursus. Dari basil penelitian ditemukan babwa tema-tema yang ditampilkan oleh al-Qur'an, berkisar pada tema penciptaan laki laki dan perempuan, kesetaraan laki laki dan perempuan, kepemimpinan, bak waris dan poligami. Diskusi atas tema tema tersebut dapat dipabami babwa cita-cita alQur'an sesunggubnya adalah tegaknya kehidupan manusia yang bermoral lubur dan menghargai nilai-nilai kemanusiaan universal (bumanisme universal). Prinsip-prinsip kemanusiaan universal itu antara lain diwnjudkan dalam upayaupaya penegakan keadilan, kesetaraan, kebersamaan, dan penghargaan terbadap hak-hak orang lain yang berlaku secara universal.

Keywords: Al-Qur'an, Equality, Gender, Interpretation.

\section{A. Pendahuluan}

Islam adalah merupakan agama yang diturunkan oleh Allah SWT di tanah Arab pada abad ke VII, termasuk agama-agama Semitik / Abraham Religious (Yahudi, Kristen dan Islam). Dalam tradisi agama Semit, kaum laki-laki selalu dianggap sebagai makhluk superior, bahkan Tuhan-pun dibayangkan sebagai laki-laki, sehingga budaya patriarkhi sangatlah kokoh.

Imbasnya, ayat-ayat suci yang diturunkan oleh Tuhan tak sedikit yang 'bernada' patriarkhis, namun banyak juga yang sebenarnya merupakan upaya menyadarkan masyarakat dari kungkungan budaya tersebut. ${ }^{1}$ Sehingga kletika Nabi Muhammad SAW berkuasa, aktivitas yang dilakukan perempuan sangatlah beragam, bahkan keluarga dekat beliau banyak ambil bagian dalam hal ini. Isteri beliau yang bernama Aisyah, ${ }^{2}$ misalnya adalah seorang

${ }^{1}$ Dalam hal ini contoh yang bisa ditunjuk dalam al-Qur'an misalnya, Islam menegaskan adanya pembagian warisan bagi perempuan, karena semula mereka tak diperhitungkan.

2 Aisyah merupakan tiga besar perawi hadits Nabi, merawikan sebanyak 3.150 hadits dengan berbagai tema seperti masalah keluarga, kewanitaan, ibadah dan sebagainya. Lihat Fathimah Utsman dan Hasan Asy’ari U, Ratu-ratu Hadits, (Yogyakarta: Ittiqa Press, 2000), h. 29 
ahli agama dan tempat bertanya bagi sahabat laki-laki dan perempuan, seorang politikus, sekaligus pekerja sosial di masyarakatnya.

Hanya saja, dalam perjalanan sejarah Islam yang harus bersentuhan dengan budaya perluasan yang masih sangat patriarkhis (Persia, Asiria dsb), sangat mempengaruhi penafsiran dan pemaknaan terhadap ayat-ayat suci yang telah ada, sehingga kesan dominasi lakilaki menjadi semakin kental. Celakanya, umat Islam banyak yang 'terjebak' dengannya, sehingga hasil ijtihad para ulama yang kemudian terumus dalam teologi Islam, Fiqih atau keilmuan yang lain, dianggap sebagai ajaran agamna yang tidak bisa diothak-athik. Padahal tidak demikian adanya.

Oleh karena itu, perlu kiranya dilakukan usaha-usaha untuk 'membongkar' pemahaman terhadap teks-teks agama yang selama ini dijadikan sebagai alat legitimasi bagi jalan pikir yang bersifat patriarkhis tersebut, yang masih jauh dari keadilan gender. Upayaupaya yang dapat mengembalikan pemahaman guna menuju tercapainya relasi kesederajatan antara laki-laki dan perempuan, sebagaimana yang dikehendaki oleh ajaran al-Qur'an dan Hadits Nabi perlu digalakkan, terutama pada tataran ilmiah, untuk selanjutnya bisa disosialisasikan kepada masyarakat.

\section{B. Reinterpretasi Atas Ayat Penciptaan Laki-Laki Dan Perempuan}

Secara kodrati, laki-laki dan perempuan merupakan makhluk Tuhan yang memiliki perbedaan-perbedaan sekaligus persamaanpersamaan. Namun hal itu bukan berarti yang satu lebih unggul/utama daripada yang lain, sehingga menyulut terjadinya ketidak-adilan dan perlakuan diskriminatif. Adanya perbedaan dan persamaan diantara keduanya merupakan sunnatullah yang sengaja diciptakan Allah demi kelangsungan hidup generasi manusia dalam mengemban tugas kekhalifahan di muka bumi.

Mengorek proses penciptaan manusia, selama ini mayoritas orang meyakini bahwa manusia pertama yang diciptakan Allah SWT adalah Adam, seorang laki-laki, sesudah itu Allah menciptakan Hawa, pasangan hidupnya. Hal ini didasarkan pada al-Qur'an surat alNisa':1. 
Artinya : "Hai sekalian manusia, bertaqwalah kepada Tubanmu yang telah menciptakan kamu dari diri yang satu, dan daripadanya Allah menciptakan pasangannya, dan daripada keduanya Allah memperkembangbiakkan laki-laki dan perempuan yang banyak. Dan bertaqwalah kepada Allah yang dengan (mempergunakan) nama-nama-Nya kamu saling meminta satu sama lain, dan (pelibaralab) bubungan silaturabim. Sesunggubnya Allab selalu menjaga dan mengawasi kamu"

Dalam memahami persoalan ini, para mufassir klasik seperti al-Zamakhsyari dan Ibnu Katsir, misalnya berpendapat tidak adil. Ibnu Katsir dalam kitabnya menjelaskan $:^{3}$ kata wa khalaqa minha zaujaha bermakna bahwa "Tuhan telah menciptakan Hawa dari tulang rusuk Adam". Hal ini dikaitkan dengan hadits Nabi yang menceritakan, ketika Adam ditempatkan sendirian di Surga, ia tidur, setelah bangun ia menjumpai seorang perempuan duduk di sebelah kepalanya, diciptakan dari tulang rusuk Adam. Ketika ditanya perempuan itu menjawab bahwa dirinya diciptakan untuk menemaninya. Lebih 'tragis' lagi jika diteruskan bahwa tulang rusuk itu mempunyai watak asli bengkok, keras dan mudah patah, yang demikian itu pula watak asli perempuan. Dia cenderung menuju ke jalan yang bengkok, serong atau menyeleweng.

Padahal al-Qur'an sendiri tidak pernah menyatakannya secara jelas tentang penciptaan perempuan secara khusus. Yang ada, alQur'an secara umum menggambarkan penciptaan manusia, jasmani dan rohani, mengenai tubuh manusia, ada dalam dua versi. Pertama, pada penciptaan awal, dalam QS.al-Hijr:26; al-Rahman:14; alShaffat:11; dan al-Nisa':1 di atas tadi.

Namun pemaknaan terhadap kata min nafsin wahidah, menurut penafsiran Yusuf Ali, a species, a nature, a similarity. ${ }^{4}$ Jadi "Allah menciptakan Adam dan Hawa dari bahan yang sama", bukan yang satu (Adam) dari tanah tetapi yang satunya (Hawa) dari tulang rusuk Adam. Sejalan dengan itu Riffaat Hassan juga membantah anggapan bahwa perempuan diciptakan dari tulang rusuk, tetapi sama-sama dari tanah. Ajaran yang menyatakan bahwa perempuan

${ }^{3}$ Ibnu Katsir, Tafsir al-Qur'an al-Adzim, (Beirut : Dar al-Fikri, 1992), h. 553

4 A.Yusuf Ali, The Holy Qur'an, Text, Translation and Commenatary, (Maryland: Amana Corp, 1983), h. 178 
diciptakan dari tulang rusuk bertentangan dengan al-Qur'an, tetapi mirip sekali dengan isi kitab Genesis 2:18-33 dan 3:20. ${ }^{5}$ Maka terhadap pandangan para mufassir klasik di atas, Nashruddin Baidan menganggap mereka lebih mendahulukan hadits ketimbang alQur'an. ${ }^{6}$

Versi kedua, al-Qur'an menjelaskan tentang kejadian manusia sesudah Adam dan Hawa, yakni reproduksi manusia. Hal ini dapat dilihat dalam QS.al-Mukminun:12-14; al-Insan:2; al-Sajdah:8; dan alQiyamah:37. Disana Allah menjelaskan bahwa tubuh manusia diciptakan dari setetes air mani yang dipancarkan dan bercampur, selanjutnya dijadikan segumpal darah, lalu segumpal daging, lalu tulang belulang dan kemudian dibungkus daging.

Adapun rohani manusia diyakini berasal dari (tiupan) Allah SW'T, sebagaimana dinyatakan dalam QS. Al-Hijr:29 dan al-Sajdah:9. Oleh karena itu manusia merupakan makhluk yang dimuliakan Allah (QS. Al-Isra:70), berstatus sebagai hamba Allah yang harus beribadah kepada-Nya (al-Dzariyat:56), dan berfungsi sebagai khalifah Allah di bumi (QS.al-Baqarah:30; Shad:26; al-An'am:165; dan Yunus:14)

Semua itu tak ada bedanya bagi laki-laki dan perempuan. Oleh karena itu hal ini hendaknya dapat dijadikan landasan pikir dalam memandang eksistensi manusia, laki-laki dan perempuan.

\section{Beberapa Konsep Kesetaraan Gender Dalam al-Qur'an}

Jika dibaca dan direnungkan, ternyata banyak ajaran al-Qur'an yang secara langsung ataupun tidak langsung menuju kepada terwujudnya kesetaraan gender. Pesan-pesan kesetaraan tersebut mencakup berbagai jenis peran dan kegiatan, baik yang berkaitan dengan eksistensi manusia maupun prestasi dan kualitasnya di hadapan Tuhan, juga di dalam masyarakatnya.

Banyak contoh yang bisa ditunjuk, misalnya Islam tidak pernah mendiskreditkan perempuan sebagai makhluk yang mudah tergoda ataupun yang menjerumuskan laki-laki, maka semua ayat al-

5 Riffaat Hassan, Teologi Perempuan Dalam Tradisi Islam, dalam Jurnal “Ulumul Qur'an” Vol. I, 1990, h. 53

6 Nashruddin Baidan, Tafsir bi al-Ra'yi, Upaya Penggalian Konsep Wanita Dalam al-Qur'an, (Yogyakarta: Pustaka Belajar, 1999), h. 7 
Qur'an yang membicarakan Adam dan pasangannya di surga sampai keduanya 'jatuh' ke bumi, selalu memakai kata ganti untuk dua orang / dhamir mutsanna (QS.al-Baqarah:35-36; al-A'raf:19-23), karenanya, perempuanpun memiliki hak yang setara dengan kewajibannya (QS. Al-Baqarah:187; dan 228).

Sebagai makhluk yang mulia, manusia laki-laki dan perempuan, dan tak pandang etnik tertentu, memiliki potensi khalifatullah (QS. Al-Baqarah:30; al-Nisa':124; dan al-Nahl:97), dengan tugas memakmurkan bumi. Bahkan laki-laki dan perempuan dapat 'bersaing' secara sehat untuk mencapai kualitas taqwa di hadapan Tuhan (QS. Al-Hujurat:13)

Berkaitan dengan kemandirian dan prestasi perempuan, Allah menghormati pilihan pribadinya, termasuk dalam hal agama, tanpa mengkaitkannya dengan keadaan/pilihan suaminya (QS.alTahrim:11); Allah memerintahkan kepada Nabi untuk mengakui sikap politik perempuan (QS.al-Mumtahanah:12); Allah meridhai perempuan untuk beramar ma'ruf nahi munkar, dan bagi mereka dijanjikan balasan rahmat dan surga (QS.al-Taubah 71-72); dalam hal berproduksi bidang ekonomi, perempuan boleh memiliki hasil kerjanya (QS.al-Nisa':32); bahkan sosok pribadi ratu Balqis penguasa negeri Saba yang baik, dibanggakan Allah (QS.al-Naml:23,32, dan 44); dalam rumah tanggapun ada kesetaraan hak dan kewajiban sebagai isteri 'di atas tempat tidur' (QS. Al-Baqarah:187)

Oleh karena itu sekiranya dijumpai ayat-ayat al-Qur'an ataupun hadits yang bernuansa dominasi pihak tertentu, ataupun bisa ditafsirkan untuk mendominasi pihak tertentu, seharusnya dicermati untuk senantiasa diselaraskan dengan ide moral kesetaraan di atas. Misalnya ketika menjumpai ayat-ayat khusus bagi laki-laki, seperti seorang suami setingkat lebih tinggi di atas isteri (al-Baqarah:228); laki-laki pelindung bagi perempuan (al-Nisa':34); laki-laki memperoleh warisan lebih banyak dari perempuan (al-Nisa':11 dan 176); laki-laki menjadi saksi efektif (al-Baqarah:228); boleh berpoligami (al-Nisa':3) dan sebagainya, menurut Nasarudin Umar tidak menyebabkan laki-laki menjadi hamba utama. Kelebihan tersebut diberikan dalam kapasitasnya sebagai anggota masyarakat 
yang memiliki peran publik dan sosial lebih, ketika al-Qur'an diturunkan. $^{7}$

\section{a. Kepemimpinan Perempuan Dalam Islam}

Walaupun telah banyak ayat-ayat al-Qur'an yang mengajarkan kesetaraan gender, namun masih banyak pihak meyakini bahwa kaum laki-laki memiliki sifat superioritas. Apalagi di bidang kepemimpinan, para mufassir klasik terutama, menegaskannya sehingga menjadi sebuah keyakinan yang sulit 'ditawar-tawar'. Keyakinan bahwa otoritas kepemimpinan hanya menjadi milik laki-laki, didasarkan pada al-Qur'an surat al-Nisa':34. Kata Qawwamun ditafsirkan oleh Ibnu Abbas sebagai pihak yang memiliki kekuasaan atau wewenang. ${ }^{8} \mathrm{Al}-$ Zamakhsyari -seorang tokoh Mu'tazilah terkemuka- menegaskan bahwa kata itu berarti laki-laki wajib beramar na'ruf nahi munkar kepada perempuan, sebagaimana penguasa kepada rakyatnya.' Jadi laki-laki diyakini sebagai makhluk yang berkuasa.

Superioritas laki-laki tersebut menurut Rasyid Ridha terjadi karena dua sebab fitri dan kasbi. Sebab fitri terlihat bahwa laki-laki lebih kuat dan berkemampuan, lebih tegap dan sempurna. Sementara sebab kasbi terlihat bahwa laki-laki lebih mampu berusaha, berinovasi dan bergerak. Oleh karena itu laki-laki dituntut untuk memberi nafkah kepada perempuan, menjaga dan memimpinnya. Di pihak lain, perempuan diberi fitrah mengandung, melahirkan, menyusui dan mendidik anak. ${ }^{10}$

Penafsiran semacam itu berimplikasi jauh, yakni perempuan tidak berhak menjadi pemimpin, bahkan mengatur hidupnya sendiri ataupun meningkatkan kualitas dirinya sebagai hamba Allah dan khalifah, apalagi memimpin orang lain. ${ }^{11}$ Tentu saja hal ini sangat

${ }^{7}$ Nasaruddin Umar, Argumen Kesetaraan Gender Perspektif al-Qur'an, Jakarta: Paramadina, 1999), h. 249

${ }^{8}$ Ibn Abbas, Tanwir al-Miqdas min Tafsir Ibn Abbas, Abu Thahir Ibn Ya'qub al-Fairuzabadi (ed.), (Beirut: Dar al-Fikr, tt), h. 69

${ }^{9}$ al-Zamakhsyari, al-Kasysyaf, Juz I, (Beirut: Dar al-Fikr, 1977), h. 523

10 Rasyid Ridha, Tafsir al-Manar, Juz V, (Beirut: Dar al-Fikr, 1973), h. 6970

11 Sampaipun ingin berpuasa (beribadah), perempuan harus seijin suaminya. Bahkan kitab Uqud al-Lujjain mengutip hadits riwayat Hakim, yang menuntut perwujudan bakti isteri terhadap suaminya secara tidak masuk akal, yakni seandainya istri menjilati darah dan nanah yang keluar dari hidung suaminya 
merugikan perempuan, di hadapan Allah maupun di mata masyarakat pada umumnya.

Oleh karena itu hendaklah dilakukan penafsiran ulang secara proporsional, misalnya terhadap QS al-Nisa':34. Ayat itu bertujuan untuk mengatur mekanisme intern dalam keluarga, bukan pengaturan atau kepemimpinan bagi dunia publik. Karena yang dimaksud al-rijal di situ adalah suami-suami, dan al-nisa' adalah isteri-isteri. Wajar jika suami yang menanggung nafkah keluarganya, menjadi pemimpin/kepala keluarganya. Namun bukan berarti isteri menjadi 'terjajah', apalagi jika isteri juga ikut bertanggung jawab terhadap tegaknya ekonomi keluarganya.

Dalam hal ini Fazlurrahman berpendapat bahwa ayat itu bukan penegasan perbedaan hakiki, tetapi fungsional./ Artinya jika isteri dapat mandiri di bidang ekonomi, atau paling tidak dapat memberikan kontribusi bagi rumah tangganya, maka keunggulan suami otomatis akan berkurang. ${ }^{12}$ Dan menurut Amina Wadud Muhsin, kata qawwamun tidaklah dimaksudkan menegaskan superioritas melekat pada setiap laki-laki. Yang dilebihkan Allah adalah sebagian mereka atas sebagian yang lain, ${ }^{13}$ dan ini realitas sejarah, bukan normatif, sehingga ayat ini berlaku umum, artinya kelebihan yang dimiliki oleh sebagian laki-laki atas laki-laki yang lain dapat berlaku juga di kalangan perempuan atas perempuan yang lain. ${ }^{14}$ Oleh karena itu, kedudukan suami sebagai kepala keluarga-pun masih patut dipertanyakan jika realitas yang mendukungnya kurang memadai.

Sementara itu, para ulama yang tidak setuju atas tampilnya perempuan menjadi pemimpin juga mencari 'dukungan' atas hadits Nabi:

(biarpun sangat busuk baunya), itupun belum cukup memenuhi hak suaminya itu. Lihat Jurnal Perempuan, No.03 Mei/Juni 1997, h. 15

12 Fazlur Rahman, Tema Pokok al-Qur'an, terj. Anas Mahyuddin, (Bandung: Pustaka. 1983), h. 72

13 Amina Wadud Muhsin, Wanita Dalam al-Qur'an, terj. Yaziar Radianti, (Bandung: Pustaka, 1992), h. 96

14 Ashghar Ali Engineer, Hak-hak Perempuan Dalam Islam, Terj. Farid Wajdi dan Cici FA, (Yogyakarta: LSPPA dan CUSO Indonesia, 1994), h. 70-73 
Artinya : "suatu bangsa yang menyerabkan urusan pemerintahannya kepada perempuan, tidak akan mencapai kesejabteraan". 15

Menurut analisis Muhammad al-Ghazali, hadits ini memang shahih baik sanad maupun matannya, ${ }^{16}$ sehingga banyak ulama dan pemikir tidak mau merekomendasi tampilnya pemimpin perempuan. Padahal jika pembacaan hadits tersebut lengkap, akan nampak jelas bahwa sebenarnya hadits itu merupakan komentar arif Nabi terhadap laporan aktual utusan beliau yang baru saja datang dari Persia.

Utusan Nabi itu bernama Abdullan Ibnu Hadzafah al-Sahmi, melaporkan perlakuan yang tak selayaknya dilakukan oleh Kisra kepada utusan Nabi tersebut. Tak lama sesudah itu, Kisra mati dibunuh oleh pengacau negara itu, dan sepeninggalnya, negara tersebut semakin kacau balau, apalagi karena sistem monarkhi, kini (waktu itu) dipimpin oleh seorang puteri Kisra yang tak punya kapasitas dan kapabilitas memadai untuk menjadi ratu. Maka selaku orang yang bujak, Nabi memberi komentar atas kejadian itu sebagaimana dalam hadits tadi. Puteri Kisra yang tak mengeri apa-apa tentang politik dan pemerintahan tentu hanya akan membawa petaka bagi negerinya.

Lain halnya jika perempuan tersebut seperti Ratu Balqis, seorang penguasa negeri Saba (kini termasuk wilayah Yaman), sezaman dengan Nabi Sulaiman as, dan terkenal memiliki kepribadian dan kemampuan seorang ratu. Kisah kepribadian dan sifat-sifat baik sang ratu dapat disimak dalam QS. Al-Naml:22-44, antara lain demokratis, adil, bijaksana, penuh dedikasi, tidak suka jalan kekerasan, tidak angkuh, bertanggng jawab, dan yang terpenting, mau menerima datangnya kebenaran (hal yang biasanya sulit dilakukan oleh seorang penguasa).

Jelas sekali bahwa al-Qur'an memuji ratu Balqis dari negeri Saba, yang artinya menurut al-Qur'an, tidak ada larangan bagi tampilnya pemimpin perempuan di berbagai arena, sampaipun memimpin bangsanya. Sebab jika sekiranya Allah melarang tampilnya

15 Abi Abdillah Muhammad Ibn Ismail al-Bukhari, Shabih Bukhari, Juz III, (Singapura: Sulaiman Mari, tt), h. 90-91

16 Syaikh Muhammad al-Ghazali, Studi Kritis atas Hadits Nabi saw, Antara Pemahaman Tekstual dan Kontekstual, Terj. Muhammad al-Baqir, (Bandung: Mizan, 1991), h. 65 
perempuan menjadi pemimpin, tentu tak akan ada cerita semacam itu dalam al-Qur'an. Dan tidak mungkin Nabi secara umum melarang perempuan menjadi pemimpin, karena itu berarti bertentangan dengan al-Qur'an. Oleh karena itu, teks hadits tadi haruslah difahami secara lengkap, bersama latar belakang yang ada, sehingga pemahaman dan penerapannya tidak bertentangan dengan semangat al-Qur'an. Dan yang terpenting jangan sampai terjadi kontradiksi antara ayat al-Qur'an dan hadits Nabi serta fakta historis. ${ }^{17}$

\section{b. Hak Kepemilikan Dan waris Bagi Perempuan}

Berbicara tentang kepemilikan dan waris, maka konotasinya adalah berkaitan dengan harta benda. Al-Qur'an menegaskan bahwa perempuan sama dengan laki-laki memperoleh hak atas hasil kerjanya, misalnya dalam QS.al-Nisa':32

yang artinya : "Dan janganlah kamu irihati terhadap apa yang dikaruniakan Allab kepada sebagian kamu lebih banyak dari sebagian yang lain. (Karena) bagi orang laki-laki ada bahagian dari apa yang mereka usabakan, dan para wanita (pun) ada bahagian dari apa yang mereka usabakan, dan mobonlah kepada Allah sebagian dari karunia-Nya. Sesunggubnya Allab Maha Mengetabui segala sesuatu".

Di zaman Nabi, sebagaimana diriwayatkan oleh Jabir bin Abdillah, bahwa bibi Jabir diceraikan suaminya. Di masa iddanya, janda tersebut bermaksud untuk memanen kurmanya, tetapi dilarang keluar rumah. Melalui seseorang, perempuan itu memohon ijin kepada Nabi, dan ternyata Nabi menjawab : "betul, petiklah kurmamu, sebab barangkali kamu dapat bersedekah dengannya, atau berbuat kebaikan". (HR.Muslim). ${ }^{19}$

Oleh karena itu apabila seorang perempuan mampu memiliki harta, baik dari hasil usaha atau kerja sendiri, ataupun sebab lain, kepemilikan tersebut tetap sah secara hukum.

Sementara tentang hak waris, al-Qur'an telah memperhitungkannya secara tegas, sebagaimana terdapat dalam QS. Al-Nisa':11 dan 176. Memang secara tekstual bahagian perempuan

${ }^{17}$ Ibid., p. 67

19 Abu Syuqqah, Jati Diri Wanita Menurut al-Qur'an dan Hadits, Terj. Mujiyo, (Bandung: al-Bayan, tt), h. 138 
adalah separo dari bahagian laki-laki. Melihat hal ini (dan ayat-ayat lain yang senada dengan itu), Fazlurrahman menawarkan suatu metode pemahaman/penafsiran al-Qur'an secara kontekstual, yakni 'memperlakukan' al-Qur'an secara utuh (misalnya dengan memperhatikan bagaimana konsep al-Qur'an yang sesungguhnya terhadap eksistensi perempuan, yang bisa dilihat pada ayat-ayat lain), kemudian memahaminya dengan mempergunakan metode hermeneutika. ${ }^{20}$

Dengan model penafsiran semacam itu akan memungkinkan suatu rumusan baru yang adil, misalnya tentang pembagian warisan. Bunyi ayat al-Qur'an memang menyatakan bahwa bagian perempuan adalah separo bagian laki-laki. Tetapi perlu diingat, pada waktu itu, yakni sebelum turunnya ayat-ayat tadi, perempuan di Arab tak pernah diperhitungkan sebagai pewaris. Jika kemudian al-Qur'an memberi bagian (biarpun hanya separo), itu berarti sudah merupakan prestasi. Dan untuk waktu itu rumusan tersebut lebih tepat, sebab jika tibatiba dari yang semula tidak diperhitungkan kemudian diberi bagian yang sama dengan laki-laki umpamanya, hanya akan menimbulkan frustasi di kalangan laki-laki, dan hal ini berbahaya bagi Islam. Apalagi perempuan Arab pada umumnya tidak memiliki tanggung jawab sebagaimana perempuan Indonesia masa kini.

Oleh karena itu, prinsip Islam adalah tetap memperhitungkan perempuan sebagai penerima harta warisan, secara kuantitas bisa sama dengan bahagian laki-laki, atau dengan rumusan lain, minimal setengah bagian laki-laki, dan laki-laki menerima warisan maksimal

20 Baca secara lengkap dalam Taufik Adnan Kamal, Neo Modernisme Fazlurrahman, (Bandung: Mizan, 1987), h. 54-57. Metode ini memuat rangkaian cara sebagai berikut: (1) Memahami kondisi aktual masyarakat Arab di saat ayat-ayat alQur'an itu diturunkan di zaman Nabi, dengan sebab-sebab yang melingkupinya. Pendekatan historis ini diharapkan dapat memenuhi tuntutan intelektual dan integritas moral, karena dari sini akan dapat ditarik isi dan pesan/ideal moral yang terkandung di dalamnya. (2) 'membawa' ayat tersebut ke tempat dimana ayat itu akan dipakai, waktu itu, disitu, sesuai dengan latar belakang yang ada.

Dengan demikian konteksnya tepat, sehingga biarpun bunyi teks tetap dijaga keasliannya, namun ada dua kemungkinan: (1) melahirkan rumusan/fatwa yang sama dengan bunyi teks, atau mungkin (2) rumusan/fatwanya berbeda tetapi mengandung ide moral yang sama dengan kandungan teks. Dan jika hal ini dilakukan berarti mengkaji pesan-pesan agama dengan metode normativitas digabung dengan historisitas, sebagaimana dikehendaki oleh Amin Abdullah, Studi Agama, Normativitas atau Historisitas, (Yogyakarta: Pustaka Pelajar, 1996) 
dua kali bagian perempuan. Kompilasi hukum Islampun memungkinkan hal itu.

\section{Peran Perempuan Dalam Menangkap Peluang}

Di jaman sekarang, kehadiran perempuan di berbagai arena kehidupan dibutuhkan, penerapan fungsi kekhalifahannya ditunggu. Karenanya pandangan adil gender seharusnya menjadi tradisi dalam masyarakat, dalam komunitas apapun, termasuk komunitas agama (Islam). Maka jangan sampai ada upaya menghambat kehadiran perempuan -biarpun dengan alasan sedang memerankan fungsi reproduksi lalu diparadokskan dengan peran produksinya, sehingga domestikasi perempuan dicarikan penguat, meski dengan dalil-dalil agama- karena hal itu tak sesuai dengan nilai kesederajatan sebagaimana terdapat dalam al-Qur'an.

Bagi umat Islam, mencermati kembali aktivitas Nabi Muhammad saw dalam konteks lahirnya teks (asbab al-wurud dan asbab al-nuzul) perlu ditempuh guna melihat secara jernih maksud sesungguhnya dari sebuah teks. Ayat-ayat al-Qur'an, dan al-Hadits mengandung nilai-nilai moral yang tinggi, namun di sisi lain merupakan kompromi dengan kultur masyarakatnya ketika itu di Arab. Ada proses kesejarahan yang terkait dalam pewahyuan, namun tetap dalam elan dasar nilai kebaikan, kebebasan, kesetaraan antar manusia.

Apabila pandangan yang seimbang terhadap laki-laki dan perempuan dapat disosialisasikan dan menjadi tradisi, baik di dalam maupun di luar rumah/dunia publik, insya Allah tidak akan ada lagi kesulitan bagi perempuan untuk mengaktualisasikan diri dan kemampuannya di berbagai sektor, baik formal maupun informal. Apalagi secara kuantitas mereka lebih banyak dan kualitas merekapun bisa diandalkan. Jangan sampai justru menjadi beban lebih-lebih korban kebijakan. Banyaknya perempuan potensial yang akhirnya harus sial (karena hanya menjadi bayangan hidup bagi suaminya), teramputansi kreativitasnya, dan terisolasi dari 'keramaian' bakat dan minatnya sendiri. Diakui atau tidak, sampai saat ini di mata masyarakat, perhatian kepada perempuan hanya sebatas keberadaannya dalam keluarga, sehingga secara sosiologis bersifat tradisional. Jika mereka 'berbuat' tetap dianggap berada dalam 
institusi keluarga, dengan memainkan peran sosial mereka sebagai isteri atau anak. Pandangan konsep positivis organisme ini, ${ }^{21}$ berarti meniadakan hak bersaing perempuan dengan laki-laki dalam berbagai segi kehidupan. ${ }^{1}$

Cara pandang seperti ini tentunya sangat merugikan kalangan perempuan, sebab walaupun diakui ada beberapa perbedaan peran, tetapi bukan berarti tidak ada segi-segi 'persamaan' yang terumus dalam gender, yakni peran-peran non kodrati manusia. Persaingan yang sehat sangat dimungkinkan karena perampuan juga memiliki hak-hak otonomi, antara lain hak politik, ekonomi, sosial, dan penentuan diri secara intelektual.

Demikian juga dalam konsep Islam. Seperti pandangan Abu Syuqqah bahwa pada dasarnya al-Qur'an dan Hadits diarahkan kepada laki-laki dan perempuan sejak penetapan kemuliaan manusia sampai tanggung jawab pidana. Jadi pada prinsipnya adalah persamaan, sedangkan perbedaannya merupakan pengecualian. Kalaupun perempuan disebut bersama laki-laki dalam khithab itu sebagai penegasan dari Allah atas kesamaannya. ${ }^{22}$ Misalnya dalam surat 3:190-195; 4:124; 16:97; 40:40; 33:35; 57:189; dan sebagainya.

Ada bukti-bukti nyata, bahwa eksistensi perempuan dihormati oleh Islam, misalnya dalam kehidupan masyarakat muslim periode awal. Oleh karena itu, jika perempuan muslimah masa kini ingin merekonstruksi citranya, tak salah sekiranya mau menengok kembali ke jaman muslim ideal (jaman Nabi dan Khulafa al-Rasyidin). Cara ini berangkat dari konsep Weber tentang model atau tipe ideal, ${ }^{23}$ yang merupakan modifikasi dan kombinasi beberapa tipe yang pernah ada. Perlu disadari bahwa bagaimanapun ada keterbatasan historis yang perlu dimengerti, maka konsep tipe ideal merupakan ide tentang suatu kenyataan, bukan wujud kenyataan itu sendiri.

${ }^{21}$ Herbert Spencer, Principles of Sosiology, (New York, 1894), h. 774

1 Kiki Muhamad Hakiki, Hadits-Haditstentangpendidikan Seks, Al-Dzikra Vol.9 No.1 Januari-JuniTahun 2015, h. 48.

22 Abu Syuqqah, Kebebasan Wanita I, terj. As'ad Yasin, (Jakarta: Gema Insani Press, 1998), h. 88

23 Max Weber, The Methodology of Social Sciences, ed. And translated by Edward A.Shils and Henry A. Finch, (New York: Free Press, 1949), h. 90 
Dalam keluarga Nabi, sebagaimana ditulis panjang lebar oleh Charis Waddy, ${ }^{24}$ dikisahkan bahwa Khadijah (isteri Nabi) adalah seorang pengusaha perempuan, sejak jauh hari sebelum menikah dengan Muhammad. Bahkan Khadijah, di samping sebagai pendorong semangat $\mathrm{Nabi}$, dia adalah penyandang finansial kegiatan dakwah beliau. Maka perempuan muslimah tidak dilarang untuk menjadi seorang pengusaha, profesional, karyawati, dan bekerja di bidang-bidang yang lain.

Lalu puteri Nabi, Fathimah, selain sebagai perawi hadits, dia adalah seorang perempuan pemberani sejak kecil. Di saat ayahandanya bersujud dan berdo'a di depan ka'bah, datanglah para pengacau mengganggu dan melempari kotoran. Fathimah membela dan membersihkan beliau, padahal tindakan itu cukup beresiko. Diapun (bersama Aisyah) termasuk regu penolong dan penyedia logistik dalam perang Uhud. Maka Islam tak melarang perempuan menjadi advokat, ataupun pekerjaan-pekerjaan sosial lainnya seperti perawat, tim palang merah dan lain-lain.

Kemudian Aisyah, isteri Nabi yang paling muda dan cantik ini banyak mengundang decak kagum -terutama menyangkut kecerdasannya- tidak saja orang lain, bahkan Nabi sendiri. Sehingga ada hadits Nabi yang berbunyi; "Dapatkan sebagian dari pengetahuan agamamu dari kekasihku ini" (sambil telunjuk beliau ke arah Aisyah). Aktivitas Aisyah sangat banyak, dia meriwayatkan sejumlah 3.145 buah hadits Nabi (termasuk tiga perawi terbesar setelah Abu Hurairah dan Ibnu Umar) dengan tema-tema yang fariatif. ${ }^{25}$ Dia aktif di medan perang dan politik, khususnya sebagai regu penolong dan penyedia logistik, bahkan pernah memimpin 40 perempuan untuk terjun langsung di perang Jamal tahun $692 \mathrm{M}$. Sehingga tak ada halangan bagi perempuan untuk menjadi tentara, dosen, pendidik, ibu nyai, muballighah, juga politikus bahkan pemimpin bangsa.

Kemudian Hafshah binti Umar, (isteri Nabi), sangat besar jasanya dalam merawat pengumpulan lembaran-lembaran al-Qur'an

${ }^{24}$ Charis Waddy, Wanita Dalam Sejarah Islam, terj. Faruk Zabidi, Jakarta: Dunia Pustaka, 1987).

25 Fathimah Usman dan Hasan Asy'ari Ulama'I, Ratu-ratu Hadits, (Yogyakarta: Ittiqa Press, 2000), h. 72 
sebelum kemudian dibukukan. Dia perawi hadits, seperti juga Aisyah, tak pernah kehabisan kata untuk bertanya kepada Nabi tentang persoalan agama, bahkan dia berani berdebat dengan beliau. Untuk profesi saat ini barangkali seorang arsiparis, penulis atau ahli seminar.

Kemudian Saudah, sebelum diperisteri Nabi, dia merupakan perempuan pertama yang berani hijrah ke Abbesinia. Dan Zainab, isteri Nabi yang dijuluki sebagai 'ibu orang miskin dan anak yatim' karena suka kegiatan sosial. Kemudian Ummu Salamah Hind, merupakan perempuan pertama yang hijrah ke Yatsrib, dalam perjalanan disiksa secara keji oleh anak buah ayahnya, dan harus terpisah dari suami (sebelum menjadi isteri Nabi) dan anak-anaknya. Sesudah menjadi isteri Nabi, dia sering menemani Nabi dalam berbagai ekspidisi, antara lain Hudaibiyah, Khaibar, Fath Makkah, pengepungan Thaif dan Haji Wada'. Banyak saran-sarannya dalam menghadapi perilaku para sahabat yang diperhatikan oleh $\mathrm{Nabi}^{26}$

Yang tak kalah pentingnya adalah keteguhan iman Ummu Habibah, Ramlah, anak Abu Sufyan, dedengkot kafir Quraisy. Suami pertamanya memeluk Kristen ketika hijrah ke Abbesynia, dan keluarganya masih memusuhi Nabi sampai Fath Makkah. Tetapi dia tetap tegar dan kokoh dalam Islam. Keteguhan hati dan iman yang patut diteladani, serta pengorbanan dan kemandirian dalam memilih kebenaran, merupakan contoh konkrit dari kaum muslimah.

Perempuan-perempuan pendamping Nabi ternyata adalah sosok yang tidak pernah 'diam' dalam dinamika umat Islam periode awal. Padahal tantangan dan hambatan yang dihadapi mereka sangatlah besar. Namun keterlibatan mereka bersama para muslimah lainnya seperti Asma' binti Abi Bakar, Binti Hatim (ahli dakwah), Rufaidah (ahli merawat korban peperangan), bibi Jabir (ahli bertani kurma), Ummu Sulaim (sering terlibat dalam berbagai peperangan serta suka bertanya kepada Nabi dalam persoalan-persoalan agama), telah menjadi bukti bahwa perempuan sudah sedemikian aktif. Aktifitas mereka masih berlanjut ketika negara masih diperintah oleh Khulafa al-Rasyidin, misalnya Ummu Haram, salah satu bibi Nabi, ikut bertempur dalam perang Cyprus tahun 649 M (jaman Khalifah Utsman).

${ }^{26}$ Abu Syuqqah, Kebebasan Wanita I, h. 233 
Hanya saja, setelah jaman dinasti Bani Umayyah yang banyak meniru pola-pola hidup raja-raja Romawi dan Persi, ${ }^{27}$ dan jaman dinasti Abbasiyah yang lebih dekat ke budaya Persi, dunia Islam diwarnai oleh tradisi baru yang tidak islami, khususnya menyangkut perlakuan terhadap perempuan. Kebiasaan pesta pora dan foya-foya 'mengharuskan' munculnya penari-penari yang mengeksploitasi tubuh perempuan, namun ironisnya mereka sekaligus melakukan pembatasan-pembatasan terhadap aktifitas perempuan yang sebenarnya merupakan budaya Bizantium, Persia dan Asiria. ${ }^{28}$ Kebiasaan memelihara Harem (bahkan ada pendidikan untuk menjadi Harem). Padahal persoalan inilah yang akhirnya menggerogoti negara dari dalam sehingga rapuh dan akhirnya mudah dirobohkan.

Oleh karena itu sudah selayaknya perempuan masa kini mau melihat kenyataan dan bisa membedakan mana yang sebenarnya islami dan mana yang bukan. Untuk itu ada beberapa hal yang perlu menjadi perhatian kita bersama, ketika kita ingin mendorong perempuan untuk berpartisipasi dalam menangkap peluang yang ada. Pertama, harus tetap disadari bahwa dalam hal peran, perempuan memiliki peran kodrati (seperti hamil, melahirkan dan menyusui dan sebagainya) yang tak bisa ditukar dan tak boleh ditolak, dan hal ini patut disyukuri sebagai amanah sekaligus karunia dari Allah SWT; serta peran non kodrati yang biasa disebur gender, yang merupakan bentukan masyarakat berdasarkan sosio-kultur yang ada disekitarnya, dan disini boleh bertukar peran, boleh berbeda-beda dan boleh tawar menawar.

Kedua, berkaitan dengan gender perempuan harus menyadari bahwa dirinya memiliki kesetaraan (bukan keseragaman) dengan kaum laki-laki, dan kaum laki-laki juga demikian halnya, sehingga antara keduanya bisa memiliki peran yang sama dan bisa juga berbeda. Sekiranya dalam kesamaaan peran, berarti ada peluang untuk bersaing secara sehat, maka perempuan perlu membekali diri dengan ilmu pengetahuan, keahlian dan ketrampilan, yang dapat diandalkan untuk bisa 'diadu' dalam persaingan tersebut. Dan jika berbeda, maka hal tersebut lebih mengacu pada terlaksananya keadilan, keamanan, keahlian dan kepantasan (norma). Selama semua 1993), h. 25

${ }^{27}$ CE.Bosworth, Dinasti-dinasti Islam, terj. Ilyas Hasan, (Bandung: Mizan,

${ }^{28}$ Charis Waddy, Wanita Dalam Sejarah Islam, h. 73-78 
itu tidak memunculkan ketidak-adilan gender, barangkali normanorma androgini (norma yang mau mengambil sikap-sikap positif dari maskulinitas dan feminitas) perlu disosialisasikan, misalnya kaum laki-laki mau menggunakan perasaan untuk berempati, dan perempuan mau menunjukkan sikap asertif dan kemandiriannya.

Ketiga, berkaitan dengan kesempatan, haruslah dihindari adanya praktek kapitalistis yang semata-mata ingin meraih keuntungan sebanyak-banyaknya tanpa mengindahkan kaidah agama yang menghendaki kesetaraan martabat, maupun norma masyarakat yang tentu saja tidak mensubordinatkan perempuan. Dalam praktek ekonomi kapitalistik, perempuan hanya dianggap sebagai komoditas yang menguntungkan, kemudian dieksploitasi semaunya sendiri; sementara kalangan perempuan sendiri menangkapnya sebagai peluang yang sayang jika dilewatkan, maka terjadilah pengeksploitasian perempuan, pelecehan ataupun ketidak adilan gender yang sangat merugikan perempuan itu sendiri. Oleh karena itu, kesadaran akan kesetaraan martabat ini sangat penting artinya karena sejalan dengan firman Allah dalam QS.al-Isra:70.

\section{E. Penutup}

Dalam banyak hal dunia Islam sampai saat ini masih ketinggalan, demikian juga kaum perempuannya. Padahal salah satu indikator penting dari keberhasilan pembangunan suatu negara adalah pembangunan manusia (human development indeks) yang terutama dilihat pada penerapan gender equality.

Sejarahpun telah membuktikan, ketika perempuan dibelenggu dalam tradisi dan dunia yang sempit (ditarik ke dalam rumah saja) akan tidak menguntungkan baik secara makro maupun mikro. Sebaliknya jika perempuan memiliki kesempatan untuk bersaing secara sehat dan benar dengan kaum laki-laki, maka kemajuan bersama akan mudah dicapai, karena pada dasarnya, yang dijadikan sebagai khalifah di bumi oleh Allah SW'T adalah manusia laki-laki dan perempuan. 


\section{Daftar Pustaka}

Abbas, Ibn, Tanwir al-Miqdas min Tafsir Ibn Abbas, Abu Thahir Ibn Ya'qub al-Fairuzabadi (ed.), Beirut : Dar al-Fikr, tt.

Abdullah, Amin, Studi Agama, Normativitas atau Historisitas, Yogyakarta : Pustaka Pelajar, 1996 .

Ali, A.Yusuf, The Holy Qur'an, Text, Translation and Commenatary, Maryland: Amana Corp, 1983.

Baidan, Nashruddin, Tafsir bi al-Ra'yi, Upaya Penggalian Konsep Wanita Dalam al-Qur'an, Yogyakarta : Pustaka Belajar, 1999.

al-Bukhari, Abi Abdillah Muhammad Ibn Ismail, Shabih Bukhari Juг, III, Singapura : Sulaiman Mari, tt.

Bosworth, CE, Dinasti-dinasti Islam, terj. Ilyas Hasan, Bandung : Mizan, 1993

Engineer, Ashghar Ali, Hak-hak Perempuan Dalam Islam, Terj. Farid Wajdi dan Cici FA, Yogyakarta : LSPPA dan CUSO Indonesia, 1994.

al-Ghazali, Muhammad, Studi Kritis atas Hadits Nabi saw, Antara Pemahaman Tekstual dan Kontekstual, Terj. Muhammad alBaqir, Bandung : Mizan, 1991

Hakiki, Kiki Muhamad, Hadits-Haditstentangpendidikan Seks, Al-Dzikra Vol.9 No.1 Januari-JuniTahun 2015.

Hassan, Riffaat, Teologi Perempuan Dalam Tradisi Islam, dalam Jurnal “Ulumul Qur'an” Vol.I, 1990.

Kamal, Taufik Adnan, Neo Modernisme Fålurrabman, Bandung : Mizan, 1987.

Katsir, Ibnu, Tafsir al-Qur'an al-Adzim, Beirut : Dar al-Fikri, 1992.

Muhsin, Amina Wadud Wanita Dalam al-Qur'an, terj. Yaziar Radianti, Bandung: Pustaka, 1992.

Rahman, Fazlur, Tema Pokok al-Qur'an, terj.Anas Mahyuddin, Bandung: Pustaka. 1983.

Ridha, Rasyid, Tafsir al-Manar Juz V, Beirut : Dar al-Fikr, 1973. 
Spencer, Herbert, Principles of Sosiology, New York, 1894.

Syuqqah, Abu, Jati Diri Wanita Menurut al-Qur'an dan Hadits, Terj. Mujiyo, Bandung : al-Bayan, tt.

, Kebebasan Wanita I, terj. As'ad Yasin, Jakarta : Gema Insani Press, 1998.

Umar, Nasaruddin, Argumen Kesetaraan Gender Perspektif al-Qur'an, Jakarta : Paramadina, 1999.

Utsman, Fathimah, dan Hasan Asy'ari U, Ratu-ratu Hadits, Yogyakarta : Ittiqa Press, 2000.

Waddy, Charis, Wanita Dalam Sejarah Islam, terj. Faruk Zabidi, Jakarta : Dunia Pustaka, 1987.

Weber, Max, The Methodology of Social Sciences, ed. And translated by Edward A.Shils and Henry A.Finch, New York : Free Press, 1949.

Zamakhsyari, al-al-Kasysyaf Juz I, Beirut : Dar al-Fikr, 1977. 
Siti Masykuroh 